\title{
The biogeography of kelps (Laminariales, Phaeophyceae): a global analysis with new insights from recent advances in molecular phylogenetics
}

\author{
John J. Bolton
}

Received: 6 April 2009 / Revised: 29 June 2010 / Accepted: 2 July 2010 / Published online: 23 July 2010

(C) Springer-Verlag and AWI 2010

\begin{abstract}
Despite their ecological and economic importance, no summary of kelp global biogeography has been produced for almost two decades. The circumscription of the order Laminariales and familial and generic relationships in the group have changed considerably recently, in the light of molecular data. A global summary and geographical analysis of kelp species and their distributions (112 species in 33 genera) is presented. These data are analysed and discussed from the perspective of the new consensus of relationships within the group, and likely evolutionary events. The putative ancestors of the kelps occur and are overwhelmingly most diverse, in the cooler waters of northern Japan. The biogeographical evidence suggests three main lines of subsequent evolution: (a) a diversification producing the four 'derived' families Alariaceae, Costariceae, Laminariaceae, and Lessoniaceae and most extant genera in the temperate northern Pacific, probably during the Miocene. (b) The evolution of an Arctic flora which invaded the North Atlantic following the opening of the Bering Strait ca. 5.5 Ma. (c) At least four separate crossings, by different genera, of tropical regions from Northern to Southern Hemisphere (and one in the opposite direction). The recorded impacts of man on these distributions have thus far been minimal, with the notable exceptions of Undaria pinnatifida and species of Saccharina (grown in aquaculture systems for human food). Most genera are monospecific, with many confined to either the western or eastern temperate North Pacific, whereas the
\end{abstract}

Communicated by Inka Bartsch.

J. J. Bolton $(\bowtie)$

Department of Botany, University of Cape Town,

Rondebosch 7701, South Africa

e-mail: John.Bolton@uct.ac.za distribution of the most species-rich genera (Alaria, Laminaria, Saccharina) includes the Arctic, and they are widespread in the North Atlantic. This rapid species-level evolution is hypothesised to have been promoted by the relatively recent invasion of the Atlantic by these taxa. The crossing of the tropics has occurred in warm-temperate species some of which occur and are sometimes abundant, in deeper water in today's tropics, refuting the widespread view that kelps are only present in cold-water habitats. Most of these Southern Hemisphere kelps are in the family Lessoniaceae, including the only genus not present in the Northern Hemisphere, Lessonia. The origins of this genus are unclear. Knowledge of the phylogeography of the Ecklonia/Eisenia complex is particularly important in understanding Southern Hemisphere kelp biogeography. A number of groups are undergoing active speciation and, with the lack of a consistent species concept, the species-level taxonomy of the group remains to be clarified. There is a great need for molecular phylogeographical studies to provide evidence for many of the hypotheses presented here based on distributional evidence and the currently accepted taxonomic framework.

Keywords Kelps · Global distribution · Evolution · Diversity · Dispersal · Laminariales

\section{Introduction}

'Kelps' is the common name for a group of large brown algae. The colloquial term 'kelps' is sometimes used to describe large brown algae in different orders, which can cause confusion as in, for example, the use of the term 'kelp' for members of the genus Durvillaea (Fraser et al. 2009). 'Kelp' is used here in the strict sense, including only members of the order Laminariales (Phaeophyceae). Many 
kelp species are ecologically dominant in shallow coastal rocky habitats in temperate and Arctic regions, although more recently extensive kelp beds have been found in tropical regions in specific cooler water habitats (Graham et al. 2007a; Santelices 2007). Larger kelps can form dense stands over large areas of the shallow rocky subtidal, often referred to as kelp beds or kelp forests, such as the giant kelp Macrocystis pyrifera in the north-eastern Pacific and southern oceans, as well as the genus Laminaria and its close relatives, on North Atlantic, North Pacific, Arctic and southwest African coasts. Species of kelps are important in many industries for human food, production of alginates (Zemke-White and Ohno 1999) as well as many other uses such as medicine (Smit 2004) and feed in abalone aquaculture (Troell et al. 2006). Undaria pinnatifida has been introduced from Japan to many temperate regions, probably as a consequence of shellfish aquaculture, and "is regarded as one of the most urgent and aggressive threats to marine ecosytems" (Uwai et al. 2006). Species of Saccharina (formerly Laminaria) have also been introduced into regions of China and Japan for purposes of cultivation as human food (Suzuki et al. 2007; Li et al. 2008).

Although kelps are so ecologically and economically important, their global biogeography has not been reviewed for almost two decades. The last major single review on global kelp distributions was in the study of Estes and Steinberg (1988). They combined distribution data with seawater temperature data and information from the fossil record of kelp-specific limpets to propose that the Laminariales radiated in the North Pacific following the onset of late Cenozoic polar cooling. In addition, the book of Lüning (1990) discusses the seaweed floras of the world in some detail and contains a number of evolutionary biogeographical hypotheses on kelps, and Lüning and Tom Dieck (1990) discussed evolutionary relationships between North Atlantic and North Pacific kelps. Following the initial pioneering molecular work (e.g. Stam et al. 1988; Fain et al. 1988; Bhattacharya and Druehl 1990; Saunders and Druehl 1991), Druehl and Saunders (1992) and Druehl et al. (1997) discussed kelp evolution and made a number of evolutionary hypotheses from the data then available.

The members of the Laminariales: molecular evidence

Since the global biogeography of this group was last summarised, molecular techniques have changed the prevailing consensus of which seaweed families comprise the Laminariales. For many years, the order Laminariales has been considered to consist of two groups of families, which have tended to be studied and discussed separately. The more typical kelp-like families the Alariaceae, Laminariaceae and Lessoniaceae were considered 'advanced' or derived (the ALL families of Lane et al. 2006), and simpler forms in a number of families were hypothesed to be ancestral (see Lüning 1990) and are basal in recent molecular phylogenies.

The ALL families were distinguished from each other based on the morphology of the frond of the sporophyte, and in particular the presence (Alariaceae) or absence (Laminariaceae) of meristems at the edges of the stipes or primary blades forming secondary blades (especially reproductive blades known as sporophylls), and whether splits occur in the primary meristem to form series' of smaller blades (present in the Lessoniaceae, which included the giant kelp, Macrocystis pyrifera) (Setchell and Gardner 1925: for a summary, see e.g. Bold and Wynne 1985). These distinctions were not clear cut with, for example, the genus Ecklonia being placed by some authors in the Laminariaceae and by others in the Alariaceae (Bolton and Anderson 1994).

Yoon et al. (2001), using data on the RuBisCo spacer (plastid encoded) and ITS region (nuclear encoded), showed that the Alariaceae, Laminariaceae and Lessoniaceae together form a monophyletic lineage. Their data separated the members of the ALL families into eight clades, and they proposed that these represented eight families, which were named. The genus Egregia, which formed its own clade as an outlier in the analysis, was assigned its own family (the Egregiaceae). Apart from using Chorda filum (Chordaceae) as an outgroup, they did not consider the ancestral families of the group, following Reviers and de Rousseau (1999) by only including the ALL families in a "Laminariales sensu stricto". Yoon et al. (2001) use the term "primitive kelp families", although if they recognise such ancestral kelp families and consider 'kelps' to be synonymous with the Laminariales, there appears to be no logic in their exclusion of these ancestral families from the order.

The current definitive treatment of the ALL is that of Lane et al. (2006). These authors sequenced a total of $6000 \mathrm{bp}$ from nuclear, plastid and mitochondrial genomes. They also concluded that the ALL group is monophyletic, but that it consists of four major clades, rather than three (or eight as in Yoon et al. 2001). They described a new family Costariaceae to include the genera Agarum, Costaria, Dictyoneurum, and Thalassiophyllum "the only genera in the Laminariales with flattened, occasionally terete, stipes, and either a perforate or reticulate blade". What we can now call the 'ACLL families' have extremely altered compositions in this new treatment with, for example, Ecklonia now being clearly in the Lessoniaceae although previously it had been either in the Laminariaceae or Alariaceae (Bolton and Anderson 1994), and with many well-known genera formerly in the Lessoniaceae being moved to the Laminariaceae (e.g. Macrocystis, Nereocystis, Postelsia). A clear separation of the genus Laminaria into two clades led these 
authors to resurrect the genus Saccharina Stackhouse for the clade of former Laminaria species not including the type of the genus, Laminaria digitata (Hudson) Lamour. Most Laminaria species have split blades whereas most Saccharina species do not but, unfortunately, this is not always the case (Lane et al. 2006). Most of the morphological characters that were thought to be critical in kelp taxonomy have been shown to have evolved separately in different clades (e.g. single blades, splitting of single blades, split stipes, stoloniferous holdfasts, etc.). As in many groups of algae, simplicity does not necessarily equate with early evolution.

The 'ancestral' members of the Laminariales are currently considered to consist of three families, the Chordaceae (four species of Chorda, Kawai et al. 2000; Sasaki and Kawai 2007), the Pseudochordaceae (two species of Pseudochorda: Kawai and Kurogi 1985; Kawai and Nabata 1990) and the Akkesiphycaceae (one species of Akkesiphycus: Kawai and Sasaki 2000). Species of Chorda and Pseudochorda have cylindrical, chord-like sporophytes, and Chorda has monoecious gametophytes and zoospores with eyespots, all considered primitive traits in this group (Maier 1984; Lüning and Tom Dieck 1990; Kawai and Sasaki 2000). Akkesiphycus lubricum, although having a sporophyte with a kelp-like form, is very different from other members of the order in that the female gametes are flagellate, rather than the non-motile eggs of all other Laminariales (Kawai and Sasaki 2000). These authors, however, point out that eggs of Laminaria angustata have been reported to have residual flagella (Motomura and Sakai 1988). The unusual alga Phaeosiphoniella cryophila, endemic to the cold waters of North Atlantic Newfoundland, has been shown by molecular evidence to have possible affinities to the Laminariales (Phillips et al. 2008), although these authors refrained from placing their new monospecific family Phaeosiphoniellaceae in an order. If Phaeosiphoniella indeed belongs in the Laminariales, there may have to be a considerable re-think of the geographical origins of the early kelps.

Aims of this contribution

The aim of this contribution is to analyse and discuss the global distribution of families, genera and species of the Laminariales following our new understanding of what constitutes the group. The existing biogeographical information will be considered in the light of published ideas on kelp evolution in order to assess and suggest improvements to previously discussed kelp biogeographical hypotheses, and to frame new questions in the light of this new consensus. The data will be analysed using the species as recognised in the literature as the basic taxonomic unit. There are problems with kelp species delimitation, which will be discussed.
Many of the kelp phylogeographical hypotheses included in this paper are discussed in the major work of Klaus Lüning (1990), which must continue to be consulted as an important source on this topic. Many of the statements presented here have an equivalent somewhere in Lüning's book (or in the other more specific summaries of Estes and Steinberg 1988; Lüning and Tom Dieck 1990; Druehl 1981; Druehl and Saunders 1992; Saunders and Druehl 1992; and other papers of Druehl and collaborators). They are, however, not pulled together in a short synthesis, and none of these authors had the benefit of the new molecular consensus of the order and families. It is considered an opportune time to resurrect some of these hypotheses, reject others, and suggest still others, based on the more recent evidence on kelp evolution. Any summaries of numbers of species in different geographical regions or numbers of species in a genus have to be viewed in the light of the prevailing confusion as to what constitutes a species. Nevertheless, the evidence we have suggests that morphological variation at the genus level corresponds to molecular variation in the majority of cases, and also that much morphological variation at what is currently considered to be the species level also has a molecular basis. It is likely to be quite a few years before a stable taxonomy is clarified, particularly at species level in the more diverse genera. Nevertheless, it is considered timeous to re-investigate the global distribution of the newly circumscribed Laminariales and to look again at possible origins and patterns of dispersal in the newly arranged kelp families.

\section{Methods}

The main body of the dataset for this analysis was downloaded from www.Algaebase.org in July 2009, with published more recent additions having been added. All species authorities can be found on the website. This website (Guiry and Guiry 2009) attempts to include all seaweed species thus far described. It is based entirely on published literature, and any taxonomic controversies are decided upon by the Webmaster of the site, Prof. Michael D. Guiry, in collaboration with other taxonomists. Minor additions or errors in the web database were made in the current dataset by the author and submitted to Algaebase for updating. The Algaebase dataset intends to provide the currently accepted name of all described species, with all properly published synonyms. This resulted in 112 species of Laminariales (Table 1). The geographical information for the current study was also extracted from Algaebase, again with slight additions or errors known to the author corrected. In particular, the genus Macrocystis is accepted to be monospecific (Coyer et al. 2001; Graham et al. 2007b, Demes et al. 2009), and the revision of Northeast 
Table 1 List of kelp species recognised in this analysis (for species authorities, see www.Algaebase.org)

\begin{tabular}{|c|c|c|}
\hline Laminariales (33 genera, 112 species) & Genus & Species \\
\hline \multicolumn{3}{|l|}{ 'Ancestral families' ( 3 genera, 7 species) } \\
\hline Akkesiphycacae ( 1 genus, 1 species) & Akkesiphycus & lubricum \\
\hline Chordaceae (1 genus, 4 species) & Chorda & asiatica, filum, kikonaiensis, rigida \\
\hline Pseudochordaceae (1 genus, 2 species) & Pseudochorda & gracilis, nagaii \\
\hline \multicolumn{3}{|l|}{ 'ACLL families’ (30 genera 105 species) } \\
\hline \multirow[t]{8}{*}{ Alariaceae ( $8^{\mathrm{a}}$ genera, $18^{\mathrm{a}}$ species $)$} & Alaria & $\begin{array}{l}\text { angusta, crassifolia, crispa, dolichorhachis, esculenta, } \\
\text { marginata, oblonga, paradisea, praelonga }\end{array}$ \\
\hline & Aureophycus ${ }^{\mathrm{a}}$ & aleuticus \\
\hline & Eualaria & fistulosa \\
\hline & Lessoniopsis & littoralis \\
\hline & Pleurophycus & gardneri \\
\hline & Pterygophora & californica \\
\hline & Undaria & crenata, pinnatifida, undarioides \\
\hline & Undariella $^{\mathrm{b}}$ & kurilensis \\
\hline \multirow[t]{4}{*}{ Costariaceae (4 genera, 7 species) } & Agarum & fimbriatum, clathratum, oharaense \\
\hline & Costaria & costata \\
\hline & Dictyoneurum & californicum, reticulatum \\
\hline & Thalassiophyllum & clathrum \\
\hline \multirow[t]{13}{*}{ Laminariaceae (13 genera, 56 species) } & Arthrothamnus & bifidus, kurilensis \\
\hline & Costularia & kurilensis \\
\hline & Cymathaere & fibrosa \\
\hline & Feditia & simuschirensis \\
\hline & Laminaria & $\begin{array}{l}\text { abyssalis, agardhii, appressirhiza, bullata, complanata, } \\
\text { cordata, digitata, ephemera, farlowii, hyperborea, } \\
\text { inclinatorhiza, longipes, multiplicata, nigripes, } \\
\text { ochroleuca, pallida, philippinensis, platymeris, } \\
\text { rodriguezii, ruprechtii, setchellii, sinclairii, } \\
\text { solidungula, yezoensis }\end{array}$ \\
\hline & Macrocystis & pyrifera \\
\hline & Nereocystis & luetkeana \\
\hline & Pelagophycus & porra \\
\hline & Phyllariella & ochotensis \\
\hline & Postelsia & palmaeformis \\
\hline & Pseudolessonia & laminarioides \\
\hline & Saccharina & $\begin{array}{l}\text { angustata, bongardiana, cichorioides, coriacea, } \\
\text { crassifolia, dentigera, groenlandica, gurjanovae, } \\
\text { gyrata, japonica, kurilensis, latissima, longicruris, } \\
\text { longipedalis, longissima, ochotensis, religiosa, } \\
\text { sculpera, sessilis, yendoana }\end{array}$ \\
\hline & Streptophyllopsis & kuroshioense \\
\hline \multirow[t]{5}{*}{ Lessoniaceae (5 genera, 24 species) } & Ecklonia & brevipes, cava, kurome, maxima, muratii, radiata, stolonifera \\
\hline & Eckloniopsis & radicosa \\
\hline & Egregia & menziesii \\
\hline & Eisenia & arborea, bicyclis, cokeri, desmarestioides, galapagensis, gracilis \\
\hline & Lessonia & $\begin{array}{l}\text { adamsiae, brevifolia, corrugata, fuscescens, nigrescens, } \\
\text { tholiformis, trabeculata, vadosa, variegata }\end{array}$ \\
\hline
\end{tabular}

a The family placement of Aureophycus is not definite, but it appears most closely related to the Alariaceae: Kawai et al. (2008)

b This is Undariella Petrov \& Kusakin, not Undariella Lee 
Pacific species of Alaria by Lane et al. 2007 is also accepted. I have omitted the Japanese and Korean species based on Laminaria peterseniana Kjellm., which has been variously placed in Undariopsis Miyabe \& Okamura or Undariella Y. Lee (Lee 1998, 1999), as it has been demonstrated to be conspecific with Undaria pinnatifida (Uwai et al. 2007). I have, however, included Undariella kurilensis (described as a new genus independently from Lee [1998] by Petrov and Kusakin 1997: see Selivanova et al. 2007). The genus Tauya is not included, as its status is in need of verification, according to Selivanova et al. (2007). The conspecificity of taxa which have been demonstrated to hybridise to some extent, but which have different distributions and differ morphologically and/or ecologically, is a problem area in kelps which will be discussed later. In the absence of convincing molecular evidence for conspecificity, I have included Laminaria platymeris and Saccharina longicruris which are considered by some authors (see Bartsch et al. 2008) to be synonyms of $L$. digitata and $S$. longissima, respectively. I have followed Bartsch et al. (2008) in considering Laminaria brasiliensis to be a synonym of $L$. abyssalis.

Algaebase gives distributions on a country basis, which is very detailed in the context of a global analysis, and has been used a number of times for sources of seaweed biogeographical data in the literature (e.g. Andreakis et al. 2007; Bolton et al. 2007). Firstly, the accepted genera with the numbers of currently accepted species in each genus are presented, tabulated in the seven families within the Laminariales accepted in this contribution.

The biogeographical analyses use the recently published hierarchical scheme of marine ecoregions proposed by Spalding et al. (2007). The biogeographical regions in this scheme were produced from extensive literature and consultation with coastal marine biogeographers around the world. The highest level of this hierarchy is represented by 'marine biogeographical realms', of which there are 12 . One of these realms is the 'Temperate North Pacific', which is considered by Spalding et al., to be a single biogeographical realm from the Sea of Japan to Baja California (see Fig. 2a in Spalding et al. 2007). Because of the extreme importance of this region in studies on the evolution and diversification of the Laminariales (Estes and Steinberg 1988; Lüning 1990), it has been split into four in the current analysis (see Fig. 1):

- Temperate Northeast Pacific (Baja California to the Canada/Alaska border) TNEP

- Alaska ALSK

- Sea of Okhotsk (including Sakhalin Island and the Kamchatka Peninsula) OKHO

- Northwest Pacific (including Japan, Korea as far south as mainland portions of the South China Sea) JAPK

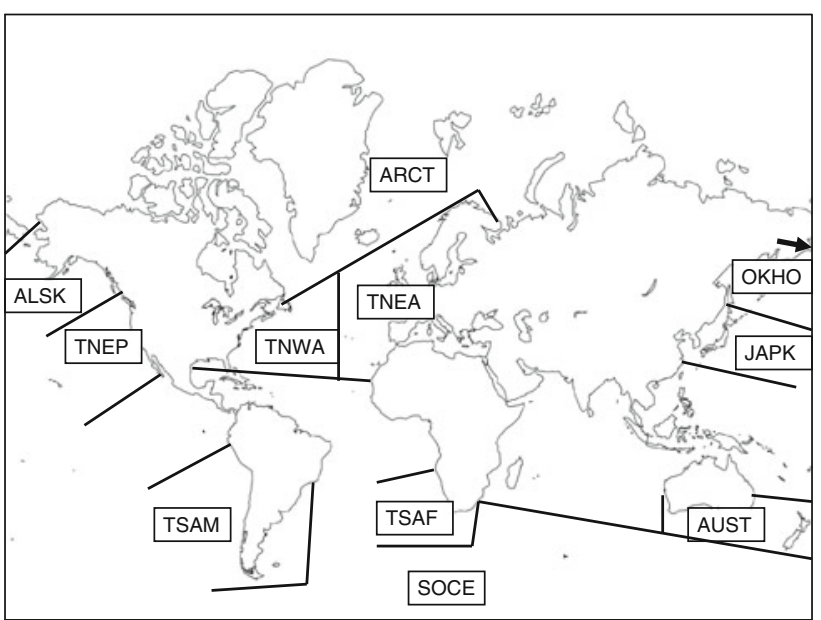

Fig. 1 The 11 world regions used for the biogeographical analysis (adapted from the system of Spalding et al. 2007, see text) (TNEP temperate Northeast Pacific, ALSK Alaska, ARCT Arctic, TNWA temperate Northwest Atlantic, TNEA temperate Northeast Atlantic, OKHO Okhotsk Sea, JAPK Japan, Korea, TSAM temperate South America, SOCE Southern Oceans, TSAF temperate South Africa, AUST Australasia)

In addition, the temperate North Atlantic realm of Spalding et al. (2007) has been split into temperate north-western Atlantic (TNWA) and temperate north-eastern Atlantic (TNEA) regions. This is because the North Atlantic is critical to our ideas of kelp biogeography (Lüning and Tom Dieck 1990; Lüning 1990), and the two sides of this ocean have rather different seaweed floras (Lüning 1990), although related on a global scale. Similarly, the cold waters of the Far-Eastern Seas of Russia (equivalent to OKHO) were separated from JAPK, as this region has been shown to have many interesting kelp taxa, different from those in the Japan/Korea region (Petrov 1974; Klochkova 1998; Selivanova et al. 2007).

There have been few records thus far of kelps in tropical or subtropical regions, and these are recorded in regions where there is local upwelling of cooler water, or cooler deep water (e.g. Laminaria in Namibia, Molloy and Bolton 1996; Ecklonia in Oman, Sheppard et al. 1992, Eisenia in Peru and the Galapagos islands, Ramírez and Santelices 1991; Graham et al. 2007a), and thus the 5 tropical regions of Spalding et al. (2007) were omitted from the numerical analyses, although these tropical occurrences will be discussed. Thus, the world is divided into 11 regions for the current analysis (Fig 1), 4 in the Southern Hemisphere (temperate South America TSAM; temperate southern Africa TSAF; temperate Australasia AUST and Southern Oceans SOCE), and 7 in the Northern Hemisphere (the 4 above, plus Arctic ARCT, temperate north-western Atlantic TNWA and temperate north-eastern Atlantic TNEA).

The kelp data are presented as number of genera and species in each family, in each of the 11 global regions. The kelp genus and species data for these regions were then 
subjected to ordination (Detrended Correspondence Analysis; DECORANA, using the option to downweight rare species) and cluster analysis (average linkage, Bray-Curtis similarity coefficient), to show how the world regions cluster with respect to their kelp floras. Data were analysed using Community Analysis Package 4.0 (Pisces Conservation Limited 2007).

\section{Results}

The current treatment recognises 112 species of Laminariales (Table 1), of which 7 are members of the 'ancestral families' and 105 members of the derived 'ACLL families'. These species are combined into 3 'ancestral genera' in 3 families, and 30 genera in the four 'derived' ACLL families: 18 of the 33 genera are monospecific. Half of kelp species and 39\% of kelp genera are in the family Laminariaceae.

The world region with the most diversity at the genus level (Table 2) is the Temperate North-East Pacific (TNEP) (19 genera $=57.6 \%)$, followed by the other subregions of the temperate North Pacific Marine realm (Alaska ALSK, Ochotsk Sea OKHO; Japan and Korea JAPK), with 13-16 genera each. The other regions have few genera, with 5 in the Arctic and Atlantic regions, and 2-4 in the Southern Hemisphere regions.

The Alariaceae has slightly more genera (Table 2) in Alaska (5) and the Northeast Pacific (4) than the Northwest Pacific (3) and Ochotsk Sea (1), with only Alaria recorded in the Arctic and North Atlantic. Most genera of the Laminariaceae are in the Okhotsk Sea (9) or Northeast Pacific and Alaska (6 each), with few (3) in Japan/Korea and one or two in the Arctic, North Atlantic and Southern Hemisphere regions. Only Laminaria and Saccharina represent this family in the Arctic and North Atlantic. Macrocystis is recorded in all four Southern Hemisphere regions, whereas Laminaria occurs in this hemisphere only in eastern South America and western Southern Africa, i.e. in the S-Atlantic where it also occurs on the island of Tristan da Cunha in the mid-South Atlantic which is not part of the Southern Ocean region (Fig. 1, Table 2).

The world region with the highest kelp species diversity is Japan/Korea (Northwest Pacific) (Table 3), with approximately a third ( 37 species $=33.0 \%$ ) of the world's species, again followed by the other North Pacific regions (25-29 species). The Arctic (14) has slightly more species than the two sides of the Atlantic (10-11). The Southern Hemisphere has low species diversity, the highest figure being 9 species in temperate South America.

Among the species-rich genera, the centre of diversity of Saccharina species is in the Northwest Pacific (JAPK, Table 4). Laminaria has a different pattern, with only two species in Japan, but 4-6 in all the other regions of the Northern Hemisphere. Alaria is most diverse in cooler regions (Sea of Okhotsk, Arctic) but as well as warmer regions of the temperate Northwest Pacific (JAPK), and with only one species now recognised in the Northeast Pacific and the North Atlantic. The other three relatively species-rich genera have significant representation in the Southern Hemisphere. Ecklonia has most species in the Southern Hemisphere, but also with three out of seven species in Japan. Eisenia has maximum species number (three) in South America, with two species in the Northeast Pacific, and one in Japan. Lessonia is the only entirely Southern Hemisphere genus of kelps, with 3-5 species in all regions of this hemisphere apart from its absence in Southern Africa.

The ordination (DECORANA; Fig. 2) and cluster analysis (Fig. 3) of global kelp genus distributions initially separate a Southern Hemisphere cluster from the rest of the world. In the Northern Hemisphere, Japan/Korea occupies a central position between a tight cluster of North Atlantic/Arctic regions, and a looser cluster of North Pacific regions.

In the global analysis of kelp species, patterns are similar but clearer, with three very separate clusters. These three

Table 2 Number of kelp genera in each of 11 world marine regions

\begin{tabular}{lccccccccccc}
\hline Family & OKHO & JAPK & ALSK & TNEP & ARCT & TNWA & TNEA & TSAM & SOCE & TSAF & AUST \\
\hline Akkesiphycaceae & 0 & 1 & 0 & 0 & 0 & 0 & 0 & 0 & 0 & 0 & 0 \\
Chordaceae & 1 & 1 & 1 & 1 & 1 & 1 & 1 & 0 & 0 & 0 & 0 \\
Pseudochordaceae & 0 & 1 & 0 & 0 & 0 & 0 & 0 & 0 & 0 & 0 & 0 \\
Alariaceae & 1 & 3 & 5 & 4 & 1 & 1 & 1 & 0 & 0 & 0 & 0 \\
Costariaceae & 2 & 2 & 4 & 5 & 1 & 1 & 0 & 0 & 0 & 0 & 0 \\
Laminariaceae & 9 & 3 & 6 & 6 & 2 & 2 & 2 & 2 & 1 & 2 & 1 \\
Lessoniaceae & 0 & 3 & 0 & 3 & 0 & 0 & 1 & 2 & 1 & 1 \\
Total genera & 13 & 14 & 16 & 19 & 5 & 5 & 5 & 4 & 2 & 3 \\
\% Age of world genera & $\mathbf{3 9 . 4}$ & $\mathbf{4 2 . 4}$ & $\mathbf{4 8 . 5}$ & $\mathbf{5 7 . 6}$ & 15.2 & 15.2 & 15.2 & 12.1 & 6.1 & 9.1 & 9.1 \\
\hline
\end{tabular}

Values of more than $35 \%$ of the world's genera are highlighted 
Table 3 Numbers of species in each kelp family in each of 11 world marine regions (for explanation of region codes, see Table 2)

\begin{tabular}{lccccccccccc}
\hline Family & OKHO & JAPK & ALSK & TNEP & ARCT & TNWA & TNEA & TSAM & SOCE & TSAF & AUST \\
\hline Akkesiphycaceae & 0 & 1 & 0 & 0 & 0 & 0 & 0 & 0 & 0 & 0 & 0 \\
Chordaceae & 1 & 4 & 1 & 1 & 1 & 1 & 1 & 0 & 0 & 0 & 0 \\
Pseudochordaceae & 0 & 2 & 0 & 0 & 0 & 0 & 0 & 0 & 0 & 0 & 0 \\
Alariaceae & 6 & 8 & 7 & 4 & 5 & 1 & 1 & 0 & 0 & 0 & 0 \\
Costariaceae & 3 & 3 & 4 & 5 & 1 & 1 & 0 & 0 & 0 & 0 & 0 \\
Laminariaceae & 19 & 14 & 13 & 16 & 7 & 7 & 8 & 2 & 2 & 2 & 1 \\
Lessoniaceae & 0 & 5 & 0 & 3 & 0 & 0 & 1 & 7 & 5 & 2 \\
Total species & 29 & 37 & 25 & 29 & 14 & 10 & 11 & 9 & 7 & 4 & 7 \\
\% Age of world species & $\mathbf{2 5 . 9}$ & $\mathbf{3 3 . 0}$ & $\mathbf{2 2 . 3}$ & $\mathbf{2 5 . 9}$ & 12.5 & 8.9 & 9.8 & 8.0 & 6.3 & 3.6 & 6.3 \\
\hline
\end{tabular}

Values with more than $20 \%$ of the world's species are highlighted

Table 4 Numbers of species in the most species-rich kelp genera in each of 11 world marine regions (for explanation of region codes, see Table 2)

\begin{tabular}{llclllllllll}
\hline & OKHO & JAPK & ALSK & TNEP & ARCT & TNWA & TNEA & TSAM & SOCE & TSAF & AUST \\
\hline Alaria (15) & 6 & 5 & 3 & 1 & 5 & 1 & 1 & 0 & 0 & 0 & 0 \\
Laminaria (22) & 6 & 2 & 4 & 6 & 4 & 4 & 6 & 1 & 1 & 1 & 0 \\
Saccharina (20) & 6 & 10 & 5 & 5 & 3 & 3 & 2 & 0 & 0 & 0 \\
Ecklonia (7) & 0 & 3 & 0 & 0 & 0 & 0 & 1 & 0 & 0 & 2 \\
Eisenia (6) & 0 & 1 & 0 & 2 & 0 & 0 & 0 & 3 & 0 & 0 \\
Lessonia (9) & 0 & 0 & 0 & 0 & 0 & 0 & 0 & 4 & 5 & 0 & 3 \\
\hline
\end{tabular}

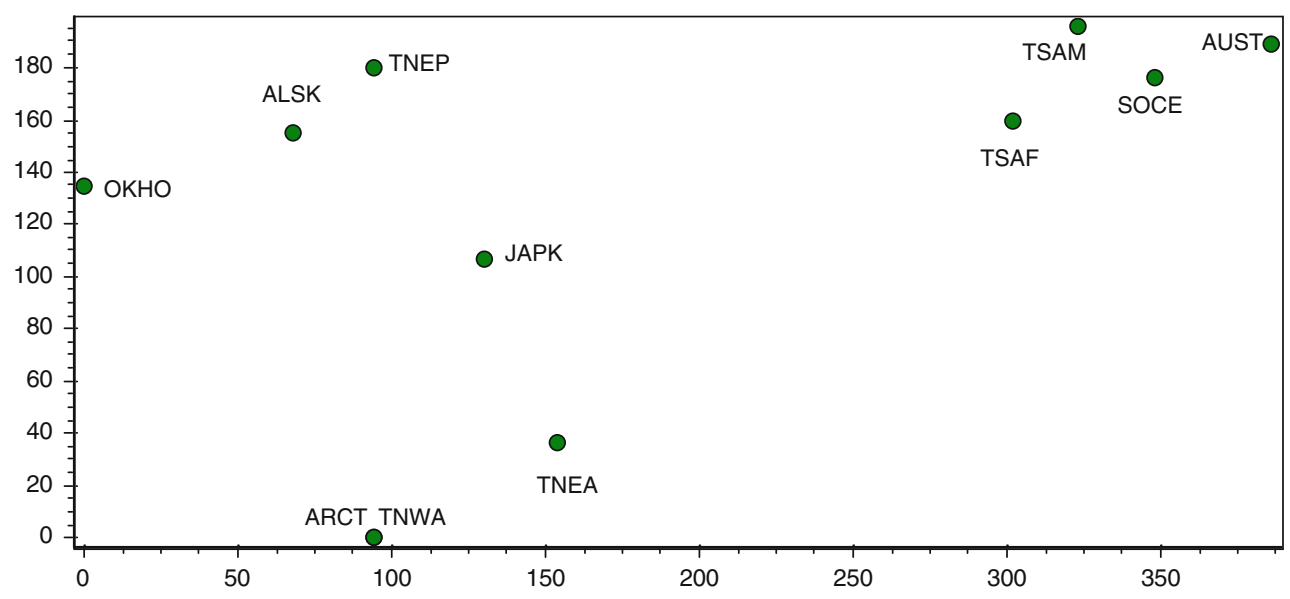

Fig. 2 DECORANA analysis of world 11 temperate marine regions, based on the kelp genera that occur in them. (Eigenvalues: Axis 1, 0.5612; Axis 2, 0.1822). Region codes as in Fig. 1

clusters were resolved in a number of other cluster analyses (not shown) involving different similarity/distance measures (Jaccard, Euclidean distance) and clustering method (complete linkage). The most distant cluster on Axis 1 (Fig. 4) and the initial split in Fig. 5 separate the four Southern Hemisphere regions. Japan/Korea again occupies a central position in the cluster analysis between two main clusters representing the North Atlantic/Artic and the other regions of the North Pacific. The cluster nearest to the Japan/Korea point comprises the neighbouring Sea of Okhotsk followed by the Northeast Pacific and Alaska. The most distant group from the Japan/Korea on Axis 2 comprises the Arctic and Atlantic regions. The analyses suggest slightly more similarity between Southern Africa and Australasia, compared to South America and the Southern Oceans. 


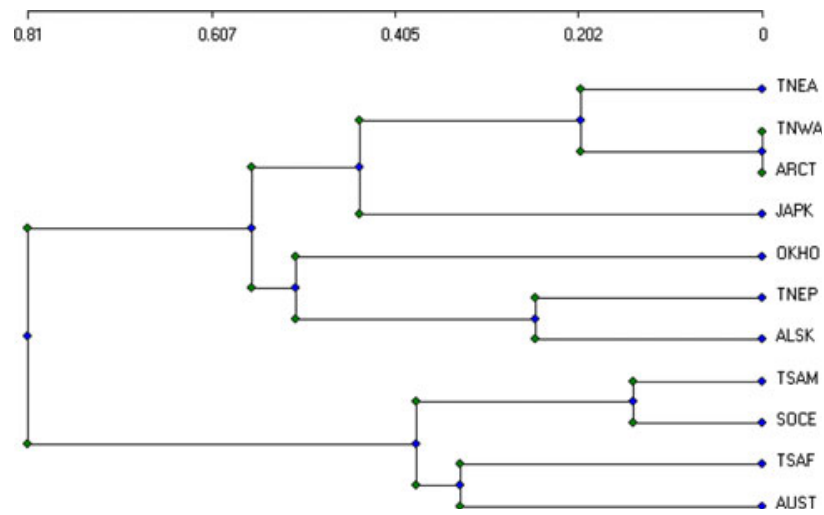

Fig. 3 Cluster analysis of 11 world temperate marine regions, based on the kelp genera that occur in them (Bray-Curtis measure, average linkage clustering). Region codes as in Fig. 1

\section{Discussion}

For a group of large organisms with such obvious global importance, the available data on kelp biogeography is surprisingly limited and still raises many questions. The techniques exist now to answer some of these questions using molecular methods, and priorities will be suggested. Some regions of the world are still not comprehensively studied, a good example being the Sea of Okhotsk and Arctic Russia, where systematic studies remain morphologically based, and there has been little recent work (e.g. Petrov 1972, 1974; Klochkova 1998; see also comments in Graham et al. 2007a; Bartsch et al. 2008). Selivanova et al. (2007) present the first study using molecular techiques in this region and also outline the many little-known taxa present. Also the occurrence and importance of kelps in tropical regions, where the clear water allows light to reach cooler depths, is an important and relatively recent area of detailed study (Graham et al. 2007a; Santelices 2007). The current contribution is still very much an interim report on global kelp biogeography.

The origins and diversification of kelps

Only a single fossil kelp is known to exist (Parker and Dawson 1965). This is Julescrania grandicornis from Miocene deposits, morphologically considered to be intermediate between extant Pelagophycus and Nereocystis. These genera are closely related (Neushul 1971; Coyer and Zaugg-Haglund 1982; Coyer et al. 1992) with both now considered members of the Laminariaceae although Pelagophycus appears from molecular data to be more related to Macrocystis than to Nereocystis (Lane et al. 2006). There is, thus, no fossil evidence available which can shed light on the origins of either the order Laminariales or of the families which make up the order. What we can ascertain from our knowledge of the distribution and relationships of extant taxa is:

- There are three separate clades currently included in the Laminariales (recognised as separate at the family level) which from molecular evidence are basal and thus represent likely ancestral lines of the order (Boo et al. 1999).

- All three groups have one or more of the following morphological traits considered to represent ancestral traits: monoecious gametophytes, anisogamous gametes, meiospores with eyespots, chord-like sporophytes.

- Six of the seven species in these three ancestral families grow in Japan, and only two of the species grow outside Japan (one in OKHO and one in TNEA).

As the majority of these ancestral Laminariales occur on the island of Hokkaido (Kawai 1986; Kawai and Sasaki 2000; Sasaki and Kawai 2007), this strongly suggests that the origins of the Laminariales were in cold-temperate regions of the Northwest Pacific. The island of Hokkaido is

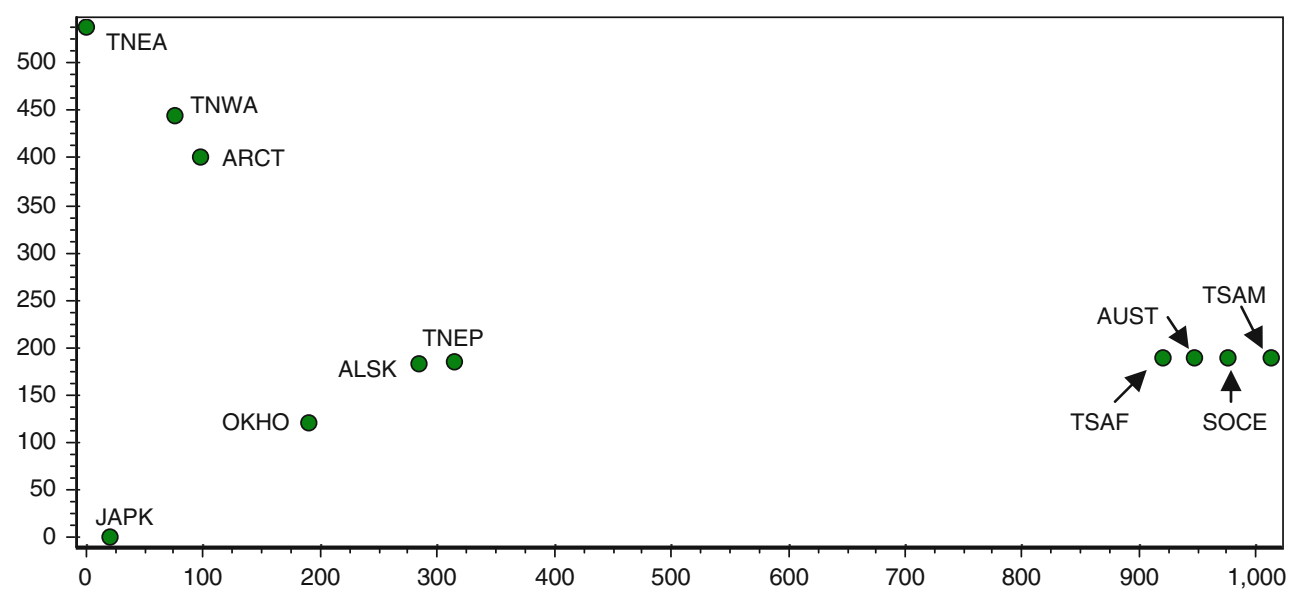

Fig. 4 DECORANA analysis of 11 world temperate marine regions, based on the kelp species that occur in them (Eigenvalues: Axis 1, 0.9414; Axis 2, 0.6482). Region codes as in Fig. 1 


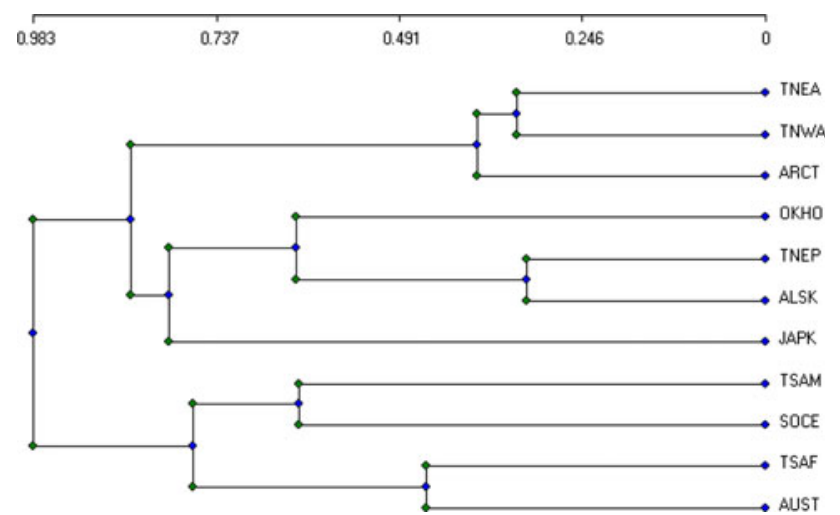

Fig. 5 Cluster analysis of 11 world temperate marine regions, based on the kelp species that occur in them (Bray-Curtis measure, average linkage clustering). Region codes as in Fig. 1

also the centre of diversity of kelp species and genera in Japan (Druehl 1968, 1981; Lüning 1990), which is part of the most species-diverse region in the current dataset although there are more kelp genera in the Northeast Pacific. The new molecular evidence removes the conundrums of the apparent occurrences of ancestral taxa outside this region. The Atlantic distribution of the Phyllariaceae (including Phyllaria and Sacchorhiza) and Halosiphon tomentosus (now Halosiphonaceae), then included in the Laminariales, caused difficulties for previous authors in discussing early origins (Estes and Steinberg 1988; Lüning and Tom Dieck 1990; Lüning 1990). The region including northern Japan is referred to by Lüning (1990) as cold temperate, using the $10^{\circ} \mathrm{C}$ winter isotherm as the border between warm and cold temperate despite the more typically tropical summer means of $25-28^{\circ} \mathrm{C}$. This suggests that the early kelps required cool water, but may have been able to survive much higher temperatures, at least for short periods. Highest temperature tolerances of kelp gametophytes of up to $29^{\circ} \mathrm{C}$ have been recorded only for Japanese kelps (Undaria, Eisenia: Tom Dieck 1993).

All four ACLL families occur in both warm temperate North Pacific regions on either side of cooler waters of Alaska and the Aleutian Islands. These families are likely to have originated and diversified in a period when the temperate Northeast and Northwest Pacific were not separated by cooler waters. Estes and Steinberg (1988) present evidence that "limpets and herbivorous mammals associated with kelps or other stipitate brown algae appeared late in the Cenozoic". This could be hypothesised to coincide with the advent of the ancestor of the ACLL families, and the start of their diversification (as most of the basal taxa, Chorda and Pseudochorda, do not have stipes which could support kelp limpets). It would be interesting to know whether there is a species of kelp-stipe limpet which occurs on Akkesiphycus.
Stam et al. (1988) presented the first molecular data for kelp phylogeography, using a DNA-DNA hybridization method, and proposed that radiation within the genus Laminaria occurred 20-15 Ma. These data need to be re-assessed using modern sequencing techniques, particularly as the genus Laminaria then included Saccharina, which is not now considered to be closely related to Laminaria within the Laminariaceae (Lane et al. 2006). There is much scope for work on molecular clocks using the data now available (see e.g. Hoarau et al. 2007 for a recent example with Fucus).

The invasion of the North Atlantic

The Laminariaceae and Alariaceae have a number of genera that occur only in temperate waters of either the Northwest or Northeast Pacific. Many of these are considered to be monospecific genera (e.g. Lessoniopsis, Pleurophycus, Pterygophora, Undariella, Pelagophycus, Postelsia, Streptophyllopsis). It is proposed that this genus-level evolution has occurred since the cooling of the Arctic Ocean and Bering Sea. It could thus be hypothesised that both these families have evolved warmer water forms, currently recognised at the genus level, separately on either side of the Arctic. It was put forward by both Estes and Steinberg (1988) and Lüning (1990) that this polar cooling occurred in the middle to late Miocene. Very few species in various families can survive both Arctic and temperate regimes (e.g. Chorda filum in the Chordaceae, Alaria esculenta in the Alariaceae, Costaria costata and Agarum clathratum in the Costariaceae, Saccharina latissima and Laminaria digitata in the Laminariaceae). The many species of Laminaria and Saccharina are generally regarded as occurring either in the Northwest or the Northeast Pacific, not both (possible exceptions being Laminaria yezoensis and Saccharina latissima). There are very few species occurring in the Arctic and both the North Pacific and North Atlantic temperate regions (possible examples being Agarum clathratum, Saccharina latissima), and they are geographically widespread, so, whether or not these populations are truly conspecific, detailed molecular population studies across their geographical range are necessary.

The current data clearly reveal a distinct kelp flora in the North Atlantic, linked closely with the Arctic flora. This concurs with the detailed discussion of previous authors (Lüning and Tom Dieck 1990; Lüning 1990) on the origins of the Atlantic kelps via the Arctic, hypothesised to have followed the opening of the Bering Strait. More recent evidence dates the first opening of the Bering Strait earlier than considered by these authors, at 5.4-5.5 Ma (Gladenkov et al. 2002). Adey et al. (2008) give a date of $3.5 \mathrm{Ma}$ for this event, citing earlier references but not Gladenkov et al. 2002. There are very few genera of kelps in the North 
Atlantic (only Laminaria, Saccharina, Alaria, Agarum: plus the record of Ecklonia in North Africa and Northeast Atlantic islands, which will be discussed later). Thus, as noted by Lüning (1990), very few kelp genera and from those genera very few species have managed to survive this trip through the Bering Strait, despite the continuous coastline available. According to Lindstrom (2001) the only kelp species which have been recorded to occur in the North Atlantic and North Pacific are Alaria esculenta, Chorda filum, and Saccharina latissima. Lindstrom (2001) was of the opinion that all three of these "may represent vicariant pairs of cryptic species", which has since been born out by the recent molecular study of Japanese Chorda (Sasaki and Kawai 2007). The latter authors demonstrate that indeed Chorda filum does not grow in Japan, and plants that previously were given this name in the Northwest Pacific were included in the new species Chorda asiatica. The order Laminariales is thus overwhelmingly a temperate rather than an Arctic group, in both likely origins and diversity. The existence of a warmtemperate kelp such as Laminaria ochroleuca in the southern Northeast Atlantic and the apparently closely related Laminaria pallida in the Southeast Atlantic (Tom Dieck 1992) is interesting with respect to the evolution of Atlantic Laminaria. Lüning and Tom Dieck (1990) commented that in the North Atlantic "warm-temperate species are probably ancestral to the cold-temperate species". Recent evidence has shown that the prevailing sea temperatures in the Arctic after the opening of the Bering Strait were much warmer than today, with sea surface temperatures as high as $18^{\circ} \mathrm{C}$ in the mid-Piacenzian era of the Pliocene, 3.0-3.3 Ma (Robinson 2009). Did Laminaria ochroleuca evolve from a coldtemperate invader, or is it more related to a warm-temperate species currently occurring in the northeast or Northwest Pacific? Interestingly, the Arctic endemic Laminaria solidungula is the only true Arctic seaweed discussed in detail by Adey et al. (2008) which does not have a clear Pacific origin, having "18 sister species", 11 of which have Pacific distributions. Molecular population studies combined with temperature tolerance studies in this genus have a great potential to shed light on the evolution of temperature tolerance in brown algae.

It is also notable that all three of the most species-rich genera of kelps (Alaria, Laminaria, Saccharina) are widespread in the Arctic and have reached the North Atlantic. Although the number of recognised species in these genera is gradually reducing (see especially the reduction to one species of Alaria in the temperate Northeast Pacific, Lane et al. 2006), from the literature, these genera are still recognised as the most species-rich. It is hypothesised that the level of morphological diversity in these genera, which has resulted in a relatively high number of species being described in each genus, is linked to their ability to colonise cold waters not available to most kelps. The relatively recent proposed time period for this colonization may offer an explanation for the presence of 'species complexes' in these genera but not in most other genera of kelps. The only exception to this pattern is the genus Agarum with three species, two of which are endemic to Japan and Kamchatka Island, and Agarum clathratum which occurs widely in the Arctic, Northeast and Northwest Pacific and Northwest Atlantic. The latter may be a more recent introduction into the Atlantic, based on the fact that it has reached Greenland (Pedersen 1976) but not the eastern North Atlantic.

Kelps in the tropics and the Southern Hemisphere

The most distant cluster from the origins in Japan in the analysis of world kelp floras represents the Southern Hemisphere. As kelps clearly originated in the Northern Hemisphere since the time when southern and northern temperate regions have been separated by permanent tropical waters - though fluctuating in extent-the ancestors of Southern Hemisphere kelps must have crossed the tropics. Kelps are warm- to cold-temperate and Arctic organisms, and they only survive in the geographical tropics under one of two conditions. Firstly, they can occur inshore in regions where large-scale upwelling brings about a temperate seawater temperature regime in shallow water, e.g. Laminaria pallida (the form previously known as L. schinzii, see Stegenga et al. 1997) in Northern Namibia (Molloy and Bolton 1996), or Eisenia and Lessonia along the coasts of Peru (Ramírez and Santelices 1991). Secondly, kelps can occur in cooler deeper water, where the clarity of tropical water enables the coincidence of enough light to grow with cool enough water for kelps to survive (Graham et al. 2007a). Examples are Eisenia galapagensis in the Galapagos Islands (Graham et al. 2007a) and, on the fringes of the tropics, Ecklonia radiata in Oman (Indian Ocean, Sheppard et al. 1992). In addition, where temperatures are extremely stable around $20^{\circ} \mathrm{C}$ throughout the year, it is possible for kelps to grow on coral reefs (e.g. Ecklonia radiata in the Houtman Abrolhos Islands off Western Australia; Hatcher et al. 1987), with both groups of organisms at the limit of their different temperature tolerances.

Which groups of kelps crossed the tropics, and where? With the new family arrangement within the Laminariales, the Lessoniaceae becomes particularly important. Three of the five genera in this family (all except Egregia and Eckloniopsis) occur in the Southern Hemisphere, although all except Lessonia occur in the Northern Hemisphere. It seems likely that the family Lessoniaceae arose in the North Pacific, as with the other ACLL families, but the genus Lessonia currently only occurs in the Southern Hemisphere. As Lessonia is not closely related to any other genus in the family Lessoniaceae, it is possible that, without fossil evidence, it may prove difficult to demonstrate 
whether the genus arose in the Southern Hemisphere, or evolved in the Northern Hemisphere where it has since become extinct. Available molecular data (Yoon et al. 2001; Lane et al. 2006) resolves most of the family into two clear clusters, with Lessonia species separating as a sister group from a clade containing Ecklonia and Eckloniopsis. These genera are closely related and may eventually be placed in a single genus in future, which would be Ecklonia. It is of interest that some of the genera have restricted distributions in the Southern Hemisphere: Lessonia has not reached southern Africa, and there is apparently no Ecklonia in South America. The outlier in the Lessoniaceae is the monospecific Northeast Pacific (Alaska to Baja California) genus Egregia, which has a more complex sporophyte morphology than other members of the family (Henkel and Murray 2007). There is much sporophyte morphological variation in the single species but little molecular variation, and the former does not coincide with the latter (Henkel et al. 2007). Egregia appears as an outlier, considered in its own family, the Egregiaceae, by Yoon et al. (2001). In many trees in Lane et al. (2006), it is also an outlier, but with a good deal of data manipulation these authors resolved Egregia into the Lessoniaceae. It is obviously an extremely interesting kelp from an evolutionary standpoint, but requires further study.

The distributional evidence suggests at least four crossings of the tropics by kelps, by Ecklonia, Macrocystis, Laminaria and Eisenia. Ecklonia has three species in Japan and three in Australasia. The diversity of the other genera in the Ecklonia clade in the North Pacific (presence of Eckloniopsis and Eisenia, also Egregia) suggests, however, that Ecklonia arose in that region, rather than in Australasia. Apart from Ecklonia brevipes in Australasia (which produces multiple uprights for a stoloniferous holdfast), Ecklonia species are morphologically rather similar in the Southern Hemisphere, with an individual solid stipe from each holdfast. The latter were considered part of an 'Ecklonia radiata complex' by Bolton and Anderson (1994). On the west coast of South Africa and southern Namibia, a larger species with a long hollow stipe, Ecklonia maxima, forms large kelp beds in the Benguela upwelling large marine ecosystem (Bolton and Anderson 1994, 1997). From hybridization experiments, this appears to be closely related to Ecklonia radiata, which grows on the adjacent south coast (Bolton and Anderson 1987), but no molecular data are yet available. In addition, Ecklonia has been reported in Atlantic North Africa and the Canaries and Cape Verde Islands (E. muratii, which was part of the Ecklonia radiata complex of Bolton and Anderson 1994) and in Oman in the northwest Indian Ocean (Ecklonia radiata, Sheppard et al. 1992). Thus, the most likely scenario for the dispersal of Ecklonia is that it spread from the Northwest Pacific to Australia and to South Africa. South African
Ecklonia could have come either from Australia (via the West Wind Drift, see Waters 2008) or from Japan (perhaps via Oman), and the evolution of the long, hollow-stiped E. maxima is likely to be an adaptive response to the higher nutrient levels in the Benguela upwelling system (Santelices et al. 2009). A route of dispersal of many red seaweed species to South Africa from Japan across the northern Indo-Pacific, via cooler localised upwellings in epochs where tropical waters were cooler, was proposed by Hommersand (1986). Finally, it is hypothesised that Ecklonia colonised the eastern North Atlantic from South Africa which, if this were substantiated by a molecular phylogeographical study, would be the only example of kelps crossing from south to north.

Most species of Eisenia occur in the Northeast Pacific (2), western South America (3) and Japan (2). It seems likely that Eisenia arose in the North Pacific and crossed the Tropics to Peru, Chile and the Galapagos. The relationships between the species are in need of investigation, with one species endemic to the Galapagos (Eisenia galapagensis, Taylor 1945), and one species endemic to Guadelupe Island (Mexico; Eisenia desmarestioides, Setchell and Gardner 1930). Both Eisenia and Ecklonia are amongst the most warm tolerant of kelps, both from their distribution and from experimental evidence (Bolton and Levitt 1985; Bolton and Anderson 1987). The genus Ecklonia does not occur in true cold-temperate regions where minimum monthly mean temperatures are below $10^{\circ} \mathrm{C}$ (Bolton and Anderson 1994). They are thus particularly well suited to crossing the tropics and indeed occur currently, sometimes in abundance, in deeper, temperate, water conditions. Graham et al. (2007a) predict, from bathymetric data and observations, the existence of more than $23,500 \mathrm{~km}^{2}$ of tropical kelp habitats, on the western coasts of the Americas and Africa (see map in Santelices 2007). This refutes a remarkably widespread but erroneous view that, to quote Estes and Steinberg (1988), "extant kelps occur exclusively in cold-water habitats". Kelps are better described as Arctic and temperate organisms, which hardly ever occur where prevailing minimum monthly mean seawater temperatures are above $20^{\circ} \mathrm{C}$ (for a rare exception, see Hatcher et al. 1987). Many kelps are limited in their distribution to warm temperate regions, where prevailing monthly mean temperatures are between 15 and $20^{\circ} \mathrm{C}$. Graham et al. (2007a) did not have good bathymetric data from the east coast of Africa (M. H. Graham, personal communication), and certainly Ecklonia quite possibly occurs in these habitats between its currently recorded limits in Mozambique (Kerry Sink, personal communication) and Oman (Sheppard et al. 1992). Graham et al. (2007a) were of the opinion that rather than representing 'stepping stones' to dispersal between hemispheres, these populations may be more continuous across the tropics than previously thought. Tests of 
this hypothesis await further observations in deeper tropical habitats. Interestingly, future studies of the ecosystems containing coelacanths, which occur in canyons with temperate upwelled water in the East African tropics, (Ribbink and Roberts 2006; Roberts et al. 2006) could produce information on these hypothesised kelp populations.

Species of Laminaria occur on both sides of the South Atlantic. On the west coasts of South Africa and Namibia, L. pallida grows mostly below $10 \mathrm{~m}$ and has a shorter, solid stipe in the southern part of its distribution and is dominant inshore, with a long, hollow stipe in the north (previously known as L. schinzii; Molloy and Bolton 1996; Stegenga et al. 1997). Lüning and Tom Dieck (1990) and Tom Dieck and de Oliveira (1993) proposed the likely scenario that these populations are derived from a dispersal event involving an ancestor of the Southeast Atlantic L. ochroleuca. Little is known of the Brazilian tropical deep-water populations of Laminaria occurring in a small upwelling near Cabo Frio. Tom Dieck and de Oliveira (1993) concluded, using hybridization studies, that the two species described were conspecific and digitate, and closely related both to eastern North Atlantic L. digitata and also, but less closely, to warm-temperate L. ochroleuca and to South African Laminaria. Either there have been two crossings of the Atlantic tropics by Laminaria, or the Brazilian and southern African Laminaria arose by dispersal from a single crossing. The latter seems plausible, bearing in mind the presence also of L. pallida on the mid-South Atlantic island Tristan da Cunha (Baardseth 1941).

Graham et al. 2007a maintain that "the western tropical Pacific and Atlantic Ocean harbour three species of deepwater Laminaria, all of which have primitive traits for the Laminariales... suggesting an ancient origin (>30 Mya) and relative permanence of deep-water kelp refugia" and that "the deep-water tropical kelp, L. philippinensis, is the most morphologically and ultrastructurally primitive extant kelp taxon". These authors are clearly only considering the Laminariales in the narrow sense (only the derived ACLL families), and it is not clear on what they base their contention that Laminaria is primitive among the ACLL families. The molecular evidence does not suggest that the Laminariaceae are more ancestral (basal) in this group than the Lessoniaceae, for example (Yoon et al. 2001; Lane et al. 2006). It is clear that single blades have been produced more than once in the Laminariaceae and that the genus with most species with entire single blades (Saccharina) is more derived than the genus with most species with split single blades (Laminaria). Splitting of the blade and splitting of the stipe have both evolved a number of times within and between different groups (Cho et al. 2006; Lane et al. 2006). The contention that $L$. philippinensis is a primitive member of the genus Laminaria is presumably based on the lack of mucilage ducts (Petrov et al. 1973), although there is no study on the evolution of mucilage ducts to back up this hypothesis. In their recent review of these taxa, Bartsch et al. (2008) make no mention of this and indeed express doubt as to the taxonomic position of the little-known L. philippinensis. Nevertheless, the study of tropical deepwater kelps is essential for our further understanding of kelp evolution, particularly in the Southern Hemisphere. It should also be mentioned that deep-water kelps occur in temperate regions with clear water, such as Laminaria rodriguezii in the Adriatic Sea (Lüning 1990), or L. ochroleuca in the Strait of Messina at $60 \mathrm{~m}$ (Drew 1972), and these should be included in any study of tropical deepwater kelps.

The genus Macrocystis occurs in the Northeast Pacific, western South America, much of the southern Ocean, and Australasia. It is absent from the Northwest Pacific and North Atlantic. It likely arose in the Northeast Pacific and has presumably spread across the tropics to South America and thence to Australasia and South Africa via the West Wind drift as floating 'rafts' which can carry many other organisms (Waters 2008). Molecular data (ITS sequences) places all Southern Hemisphere isolates (formerly considered to represent three separate species) in the same clade, most closely related to specimens from the most southern sites in the Northeast Pacific (Santa Catalina Island, California and Bahia Tortugas, Baja California, Mexico) (Coyer et al. 2001). This is evidence that the crossing of the tropics by Macrocystis has only been successful on a single occasion.

Towards a species concept for kelps

This contribution discusses distribution data for kelp genera and species, and it needs to be explained that there are problems with what constitutes a species and a genus. There is no commonly accepted species concept in seaweeds in general (Wattier and Maggs 2001), and kelps are no exception to this. There are many reports of successful hybridization between accepted closely related species of Laminariales, and even members of different genera have been suggested to be at least partially fertile (Coyer et al. 1992). If the biological species concept were to be followed in kelps, it would require a clear definition of what constitutes a successful cross (hybridization event). As Liptak and Druehl (2000) and Bartsch et al. (2008) point out, the hybridization to the F1 generation is not sufficient, and what is required is evidence of hybridization at least to the F2 generation, combined with molecular evidence of true hybridization. A discussion is also necessary on whether it is feasible or useful to apply a biological species concept to kelps. There is also now good evidence for the development of female gametophytes without fertilization, with full-size parthenosporophytes occurring in nature (Oppliger 
et al. 2007). Liptak and Druehl (2000), however, provided molecular evidence for their production of a true hybrid sporophyte blade in crosses between Alaria marginata and Lessoniopsis littoralis. Lessoniopsis has since been shown to be a member of the Alariaceae (Saunders and Druehl 1993: previously in the Lessoniaceae) and thus this is molecular evidence of at least one intergeneric hybrid (rather than inter-familial as described by the authors, provided Lessoniopsis is indeed distinct from Alaria).

Most kelp species have been described based on morphological and anatomical characteristics of the sporophytes, although morphological characters are few and many are highly plastic. The best studied group is Laminaria sensu lato (comprising Laminaria and Saccharina), reviewed by Bartsch et al. (2008). They conclude, for example, that molecular evidence shows that $L$. saccharina (now Saccharina latissima) "is a huge Pacific-Atlantic species complex with a broad plasticity, as had already been assumed after the successful hybridization experiments in this species complex in the 1970s and 1980s". This species complex includes five currently recognised species in the North Atlantic, and many in the North Pacific. It is possible that further studies including molecular techiques, will reduce this number of recognised species, as has been the case recently with global Macrocystis (Coyer et al. 2001; Demes et al. 2009) and Northeast Pacific Alaria (Lane et al. 2007).

A number of studies have been carried out on population-level variation along environmental gradients within a species or between closely related species (e.g. wave action, Roberson and Coyer 2004; Henkel et al. 2007, or temperature, Bolton and Anderson 1987). In recent studies incorporating molecular evidence, a pattern is emerging of molecular variation along environmental gradients which correlates with a level of morphological variation which in the past may have been used to describe different species. Authors describe this as "incipient speciation" (e.g. Roberson and Coyer 2004, with Eisenia), or the more erudite "species in statu nascendi" (e.g. Miller et al. 2000, with Pelagophycus). In the other major group of large brown algae, the Fucales, similar patterns exist, with hybridization between recognised species as well as hybrid geographical populations (e.g. Coyer et al. 2002b, 2006, 2007). There is an enormous amount of work still to be done at the interface between population differentiation and speciation in the Laminariales.

The level of genus in the kelp taxonomic hierarchy is also not without contention with Druehl and Saunders (1992), in what they describe as a "speculative scheme", proposing a reduction to nine genera only. More generally, the genetic relatedness between taxa at the same level of the hierarchy is less in brown than in red algae, for example (Saunders et al. 1992). This proposal for reduction in the number of kelp genera has thus far not been followed by later authors (notably including Druehl and Saunders themselves), although Cymathaere, Kjellmanniella and Hedophyllum are now considered species of Saccharina by Lane et al. (2006) (see also Yotsukura et al. 1999). There has, rather, been a slight increase in recognised genera, with Pseudolessonia (Cho et al. 2006), Aureophycus (Kawai et al. 2008) and even Druehlia (Lane et al. 2007; reduced to synonomy with the earlier Eualaria, Wynne 2009) being recently described, as well as the re-recognition of Saccharina (Lane et al. 2006). In addition, the literature on the Far-Eastern Seas of Russia is now becoming more widely known, which includes genera such as Phyllariella, Costularia and Feditia (Selivanova et al. 2007).

The problem of taxonomic rank in kelps needs much more data, both molecular and morphological on a wider range of taxa, to be clarified. It is possible that there are too many species recognised in this contribution in the genera Laminaria, Saccharina and Alaria. Although this has been thought to be the case for at least two decades, we are not much closer to solving the problem, particularly because no consistent species concept is used by different authors, and because no comprehensive studies have been carried out over the whole range of distribution of these genera. A good example is the study of Lane et al. (2007), who on molecular evidence conclude that there is only one species of Alaria in the Northeast Pacific, while still accepting a number of species in the Northwest Pacific, which have not been studied in this way. Another example of these difficulties is in Saccharina latissima and S. longicruris, the former with a short, solid stipe, and the latter with a long, hollow stipe. Lindstrom (2001) states that these two taxa are generally accepted as being synonymous. Bartsch et al. 2008 also point out that there is much evidence that the taxa are conspecific, but as final taxonomic decisions have not been published, ecologists continue to publish studies on Saccharina (or Laminaria) longicruris (e.g. Lyons and Scheibling 2007; Saunders and Metaxas 2007). To my knowledge, there has been no definitive molecular taxonomic study on the possible conspecificity of these two taxa, although Baartsch et al. (2008) cite the published abstract of Cho et al. (2006) and are of the opinion that "there is much evidence ... that $S$. longicruris is conspecific with $S$. latissima. There needs to be a consensus on how to deal with "incipient speciation" within genera: that is the existence of morphological forms with relatively slight differences within species, which have different ecologies, and can be separated molecularly (Yotsukura et al. 1999; Miller et al. 2000; Erting et al. 2004; Roberson and Coyer 2004; Lane et al. 2007; Uwai et al. 2007). As Lindstrom (2001) states: "more work is required to understand vicariance in seaweeds, especially in deciphering when a speciation event has occurred". Combined studies of the morphology, 
molecular systematics, and ecology of the speciation process will be important for our future understanding of kelp evolution. This has been better studied to date in the other main family of large brown algae, the Fucales (see Coyer et al. 2006 for a recent study on the genus Fucus). It is interesting to note the maintenance of the taxonomic rank of species for entities which hybridise in these detailed molecular studies (e.g. Coyer et al. 2002a, b; Billard et al. 2005), as well of the erection of new species on molecular/ morphological evidence (e.g. Bergstrom et al. 2005).

\section{General conclusions}

To conclude, a new and potentially very productive phase in the study of kelp evolutionary biogeography has been initiated, where molecular tools are being used to test hypotheses. Kelps clearly have sufficient dispersal barriers to enable us to hypothesise about early evolution from present-day distributions. This is borne out by the fact that all genera, even those including floating species such as Macrocystis pyrifera, Nereocystis luetkeana and Ecklonia maxima, are absent from many world regions where they could grow (note for example that only floating Nereocystis has been recorded in cooler waters of the Northwest Pacific, where it has not apparently established, Selivanova et al. 2007). In addition, accidental or deliberate human introductions of the important human food items Undaria pinnatifida (wakame) and Saccharina species (kombu) from Japan to many world regions have proved successful (Uwai et al. 2006; Suzuki et al. 2007; Li et al. 2008). Species numbers in the three most diverse genera are being reduced, and it is very likely that this reduction will continue, although some taxonomic system that can recognise the greater range of morphological variation in these genera may be useful. It is possible that a few further genera will be subsumed, but also a small number are being discovered or newly recognised. Detailed molecular studies need to be combined with morphological and ecological studies in regions and taxa where speciation is occurring, and in those which are particularly interesting from a phylogeographical standpoint. These include the mostly cool temperate genera Laminaria, Saccharina and Alaria, as well as the four genera, mostly warm temperate taxa, which have dispersed into the Southern Hemisphere (Laminaria, Macrocystis, Eisenia and Ecklonia). It is particularly important for collaborative research to occur between scientists in the northeast and Northwest Pacific, as work in the past on kelps from these two main sites of diversity have generally included mostly species (and ideas) from one or the other. These studies need to include the Far-Eastern Seas of Russia (called here 'Sea of Okhotsk) which is a major centre of kelp diversity, with a literature only recently becoming generally available (see Selivanova et al. 2007). The relationship between the only exclusively Southern Hemisphere genus (Lessonia) and its relatives is in need of further study to see if any light can be cast on its origins. Further studies of tropical deep-water kelp populations, particularly molecular phylogeography, would be of great interest. Finally, the 'molecular clock' approach needs to be applied using modern data to test possible dates of evolution of taxonomic levels in the newly circumscribed Laminariales.

Acknowledgments Thanks are due to Michael Guiry and his collaborators for their invaluable website (www.Algaebase.org) which made this contribution possible, and to Terry Hedderson for expertly clarifying some of the mysteries of molecular taxonomy. Funding is acknowledged from the National Research Foundation and the Department of Environmental Affairs and Tourism (South Africa).

\section{References}

Adey WH, Lindstrom SC, Hommersand MH, Muller KM (2008) The biogeographic origin of Arctic endemic seaweeds: a thermogeographic view. J Phycol 44:1384-1394

Andreakis N, Procaccini G, Maggs C, Kooistra WHCF (2007) Phylogeography of the invasive seaweed Asparagopsis (Bonnemaisoniales, Rhodophyta) reveals cryptic diversity. Mol Ecol 16:2285-2299

Baardseth E (1941) The marine algae of Tristan da Cunha. Results of the Norwegian Scientific Expedition to Tristan da Cunha 19371938, 9:1-137

Bartsch I, Wiencke C, Bischof K, Buchholz CM, Buck H, Eggert A, Feuerpfeil P, Hanelt D, Jacobsen S, Karez R, Karsten U, Molis M, Roleda MY, Schubert H, Schumann R, Valentin K, Weinberger F, Wiese J (2008) The genus Laminaria sensu lato: recent insights and developments. Eur J Phycol 43:1-86

Bergstrom L, Tatarenkov A, Johannesson K, Jőnsson RB, Kautsky L (2005) Genetic and morphological identification of Fucus radicans sp. nov. (Fucales, Phaeophyceae) in the brackish Baltic Sea. J Phycol 41:1025-1038

Bhattacharya D, Druehl LD (1990) Restriction enzyme analysis of variation and taxonomy in the kelp genus Laminaria (Laminariales, Phaeophyta). Hydrobiologia 204:105-110

Billard E, Daguin C, Pearson G, Serrão E, Engel C, Valero M (2005) Genetic isolation between three closely related taxa: Fucus vesiculosus, F. spiralis and F. ceranoides. J Phycol 41:900-905

Bold HC, Wynne MJ (1985) Introduction to the Algae, 2nd edn. Prentice-Hall Inc., Englewood Cliffs

Bolton JJ, Anderson RJ (1987) The temperature tolerances of two southern African Ecklonia species, and of hybrids between them. Mar Biol 96:293-297

Bolton JJ, Anderson RJ (1994) Ecklonia. In: Akatsuka I (ed) Biology of economic Algae. SPB Academic Publications, The Hague, pp 385-406

Bolton JJ, Anderson RJ (1997) Marine vegetation. In: Cowling RM, Richardson DM, Pierce SM (eds) Vegetation of Southern Africa. Cambridge University Press, Cambridge, pp 348-375

Bolton JJ, Levitt GJ (1985) Light and temperature requirements for growth and reproduction in gametophytes of Ecklonia maxima. Mar Biol 87:131-135

Bolton JJ, Oyieke HA, Gwada P (2007) The seaweeds of Kenya: checklist, history of seaweed study, coastal environment, and analysis of seaweed diversity and biogeography. S Afr J Bot 73:76-88

Boo SM, Lee WJ, Yoon HS, Kata A, Kawai H (1999) Molecular phylogeny of Laminariales (Phaeophyceae) inferred from small subunit ribosomal DNA sequences. Phycol Res 47:109-114 
Cho GY, Klochkova NG, Krupnova TN, Boo SM (2006) The reclassification of Lessonia laminarioides (Laminariales, Phaeophyceae): Pseudolessonia gen. nov. J Phycol 42:1289-1299

Coyer JA, Zaugg-Haglund AC (1982) A demographic study of the elk kelp, Pelagophycus porra (Laminariales, Lessoniaceae), with notes on Pelagophycus $\times$ Macrocystis hybrids. Phycologia 21:399-407

Coyer JA, Engle JM, Zimmerman RC (1992) Discovery of a fertile Pelagophycus $\times$ Macrocystis (Phaeophyta) putative hybrid and subsequent production of F2 sporophytes in the laboratory. J Phycol 28:127-130

Coyer JA, Smith GJ, Andersen RA (2001) Evolution of Macrocystis spp. (Phaeophyceae) as determined by ITS1 and ITS2 sequences. J Phycol 37:574-585

Coyer JA, Peters AF, Hoarau G, Stam WT, Olsen JL (2002a) Inheritance patterns of ITS1, chloroplasts and mitochondria in artificial hybrids of the seaweeds Fucus serratus and F. evanescens (Phaeophyceae). Eur J Phycol 37:173-178

Coyer JA, Peters AF, Hoarau G, Stam WT, Olsen JL (2002b) Hybridisation of the marine seaweeds, Fucus serratus and F. evanescens (Heterokontophyta; Phaeophyceae) in a century-old zone of secondary contact. Proc R Soc Lon B 269:1829-1834

Coyer JA, Hoarau G, Oudot-LeSecq M-P, Stam WT, Olsen JL (2006) An mtDNA-based phylogeny of the brown algal genus Fucus (Heterokontophyta; Phaeophyta). Mol Phylogenet Evol 39:209-222

Coyer JA, Hoarau G, Sam WT, Olsen JL (2007) Hybridization and introgression in a mixed population of the intertidal seaweeds Fucus distichus and F. serratus. J Evol Biol 20:2322-2333

Demes KW, Graham KH, Suskiewicz TS (2009) Phenotypic plasticity reconciles incongruous molecular and morphological taxonomies: the giant kelp Macrocystis (Laminariales, Phaeophyceae) is a monospecific genus. J Phycol 45:1266-1269

Drew EA (1972) Growth of a kelp forest at 60 metres in the Straits of Messina. Mem Biol Mar Oceanogr 2:135-157

Druehl LD (1968) Taxonomy and distribution of northeast Pacific species of Laminaria. Can J Bot 46:539-547

Druehl LD (1981) The distribution of Laminariales in the North Pacific with reference to environmental influences. In: Scudder GGE, Reveal JL (eds). Evolution today. Proceedings of the second international congress of systematics and evolutionary biology. Hunt Institute for Botanical Documentation. Carnegie-Mellon University, Pittsburgh, pp 55-67

Druehl LD, Saunders GW (1992) Molecular explorations in kelp evolution. Prog Phycol Res 8:47-83

Druehl LD, Mayes C, Tan IH, Saunders GW (1997) Molecular and morphological phylogenies of kelp and associated brown algae. Plant Syst Evol 11(suppl):221-235

Erting L, Daugbjerg N, Pedersen PM (2004) Nucleotide diversity within and between four species of Laminaria (Phaeophyceae) analyzed using partial LSU and ITS rDNA sequences and AFLP. Eur J Phycol 39:243-256

Estes JA, Steinberg PD (1988) Predation, herbivory, and kelp evolution. Paleobiology 14:19-36

Fain SR, Druehl LD, Baillie DL (1988) Repeat and single copy sequences are differentially conserved in the evolution of kelp chloroplast DNA. J Phycol 24:292-302

Fraser CI, Nikula R, Spencer HG, Waters JM (2009) Kelp genes reveal effects of sub-Antarctic sea ice during the Last Glacial Maximum. PNAS 106:3249-3253

Gladenkov AY, Oleinik AE, Marincovich L, Barinov KB (2002) Palaeogeog Palaeoclim Palaeoecol 183:321-328

Graham MH, Kinlan BP, Druehl LD, Garske LE, Banks S (2007a) Deep-water kelp refugia as potential hotspots of tropical marine diversity and productivity. PNAS 104:16576-16580

Graham MH, Vasquez JA, Buschmann AH (2007b) Global ecology of the giant kelp Macrocystis: from ecotypes to ecosystems. Oceanogr Mar Biol 45:39-88
Guiry MD, Guiry GM (2009) AlgaeBase. World-wide electronic publication, National University of Ireland, Galway. http://www. algaebase.org; searched during July 2009

Hatcher BG, Kirkman H, Wood WF (1987) Growth of the kelp Ecklonia radiata near the northern limit of its range in Western Australia. Mar Biol 95:63-73

Henkel SK, Murray SN (2007) Reproduction and morphological variation in Southern California populations of the lower intertidal kelp Egregia menziesii (Laminariales). J Phycol 43:242-255

Henkel SK, Hofmann GE, Whitmer AC (2007) Morphological and genetic variation in Egregia menziesii over a latitudinal gradient. Bot Mar 50:159-170

Hoarau G, Coyer JA, Oudot-Le Secq MP, Stam WT, Olsen JL (2007) Glacial refugia and recolonization pathways in the brown seaweed Fucus serratus. Mol Ecol 16:3606-3636

Hommersand MH (1986) The biogeography of the South African marine red algae-a model. Bot Mar 29:257-270

Kawai H (1986) Life history and systematic position of Akkesiphycus lubricus (Phaeophyceae). J Phycol 22:286-291

Kawai H, Kurogi M (1985) On the life history of Pseudochorda nagaii (Pseudochordaceae fam. nov.) and its transfer from the Chordariales to the Laminariales (Phaeophyta). Phycologia 24:289-296

Kawai H, Nabata S (1990) Life history and systematic position of Pseudochorda gracilis sp. nov. (Laminariales, Phaeophyceae). J Phycol 26:721-727

Kawai H, Sasaki H (2000) Molecular phylogeny of the brown algal genera Akkesiphycus and Halosiphon (Laminariales), resulting in the circumscription of the new families Akkesiphycaceae and Halosiphonaceae. Phycologia 39:416-428

Kawai H, Sasaki H, Maeda Y, Arai S (2000) Morphology, life history, and molecular phylogeny of Chorda rigida, sp. nov. (Laminariales, Phaeophyceae) from the Sea of Japan and the genetic diversity of Chorda filum. J Phycol 37:130-142

Kawai H, Hanyuda T, Lindeberg M, Lindstrom SC (2008) Morphology and molecular phylogeny of Aureophycus aleuticus gen. et sp. nov. (Laminariales, Phaeophyceae) from the Aleutian Islands. J Phycol 44:1013-1021

Klochkova NG (1998) An annotated bibliography of marine macroalgae on northwest coast of the Bering Sea and the southeast Kamchatka: the first revision of flora. Algae 13:375-418

Lane CE, Mayes C, Druehl LD, Saunders GW (2006) A multigene molecular investigation of the kelp (Laminariales, Phaeophyceae) supports substantial taxonomic re-organisation. J Phycol 42:493512

Lane CE, Lindstrom SC, Saunders GW (2007) A molecular assessment of northeast Pacific Alaria species with reference to the utility of DNA barcoding. Mol Phylogenet Evol 44:634-648

Lee Y-P (1998) Undariella, a new genus of the Alariaceae (Laminariales, Phaeophyta). Algae (Korean J Phycol) 13:419-426

Lee Y-P (1999) Nomenclatural correction of Undariella, a new genus of the Alariaceae (Laminariales, Phaeophyta). Algae 14:79

Li BJ, Sh YY, Yang G-P, Shi C, Li X-J, Cong Z (2008) Microsatellite DNA variation of the gametophyte clones isolated from introduced Laminaria japonica (Phaeophyta) and L. longissima of China and varieties derived from them. J Integr Plant Biol 50:352-359

Lindstrom SC (2001) The Bering Strait connection: dispersal and speciation in boreal macroalgae. J Biogeogr 28:243-251

Liptak MK, Druehl LD (2000) Molecular evidence for an interfamilial laminarialean cross. Eur J Phycol 35:135-142

Lüning K (1990) Seaweeds: their environment, biogeography and ecophysiology. John Wiley, New York 527 pp

Lüning K, Tom Dieck I (1990) The distribution and evolution of the Laminariales: North Pacific_Atlantic relationships. In: Garbary DJ, South GR (eds) Evolutionary biogeography of the marine Algae of the North Atlantic. NATO ASI Series, Springer, Berlin, pp 187-204 
Lyons DA, Scheibling RE (2007) Differences in somatic and gonadic growth of sea urchins (Strongylocentrotus droebachiensis) fed kelp (Laminaria longicruris) or the invasive alga Codium fragile ssp. tomentosoides are related to energy acquisition. Mar Biol 152:285-295

Maier I (1984) Culture studies on Chorda tomentosa Lyngye (Phaeophyta, Laminariales). Br Phycol J 19:95-106

Miller KA, Olsen JL, Stam WT (2000) Genetic divergence correlates with morphological and ecological subdivision in the deep-water elk kelp, Pelagophycus porra (Phaeophyceae). J Phycol 36:862-870

Molloy FJ, Bolton JJ (1996) The effects of wave exposure and depth on the morphology of inshore populations of the Namibian kelp, Laminaria schinzii Foslie. Bot Mar 39:525-531

Motomura T, Sakai Y (1988) The occurrence of flagellated eggs in Laminaria angustata (Phaeophyta, Laminariales). J Phycol 24:282-285

Neushul M (1971) The species of Macrocystis with particular reference to those of North and South America. Nova Hedwigia (Beiheft) 32:223-228

Oppliger LV, Correa JA, Peters AF (2007) Parthenogenesis in the brown alga Lessonia nigrescens (Laminariales, Phaeophyceae) from central Chile. J Phycol 43:1295-1301

Parker BC, Dawson EY (1965) Non-calcareous marine algae from California Miocene marine deposits. Nova Hedwigia 10:273-295

Pedersen PM (1976) Marine, benthic algae from southernmost Greenland. Meddr Grønland 199:1-79

Petrov JE (1972) De systemate specierum nonnullarum Laminariae Lamour. ex Orientre Extremo. Novosti Sistematiki Nizshrikh Rastenii 9:47-58

Petrov JE (1974) Synoptic key of the Orders Laminariales and Fucales from the seas of the USSR (Clavis synoptica Laminarialium et Fucalium e maribus URSS) (English translation by T. Widdowson). Novosti Sistematiki Nizshrikh Rastenii 11:153-169

Petrov YP, Kusakin OG (1997) Undariella kurilensis: a new genus and species of laminariaceous algae for the intertidal zone of Yankich Island (Kurile Islands). Biol Morya 23:79-83

Petrov JE, Suchovejeva MV, Avdejev GV (1973) Species Generis Laminaria Lam. e. mari Phillippinensi nova. Novosti Sistematiki Nizshrikh Rastenii 10:59-61

Phillips N, Burrowes R, Rousseau F, De Reviers B, Saunders GW (2008) Resolving evolutionary relationships among the brown algae using chloroplast and nuclear genes. J Phycol 44:394-405

Ramírez ME, Santelices B (1991) Catálogo de las algas marinas bentónicas de la costa temperada del Pacífico de Sudamérica. Monogr Biol 5:1-437

Reviers B, de Rousseau F (1999) Towards a new classification of the brown algae. Prog Phys Res 13:107-201

Ribbink AJ, Roberts M (2006) African coelacanth ecosystem programme: an overview of the conference contributions. S Afr J Sci 102:409-415

Roberson LM, Coyer JA (2004) Variation in blade morphology of the kelp Eisenia arborea: incipient speciation due to local water motion? Mar Ecol Prog Ser 282:115-128

Roberts MJ, Ribbink AJ, Morris T, van den Berg MA, Engelbrecht DC, Harding RT (2006) Oceanographic environment of the Sodwana Bay coelacanths (Latimeria chalumnae), South Africa. S Afr J Sci 102:435-443

Robinson MM (2009) New quantitative evidence of extreme warmth in the Pliocene Arctic. Stratigraphy 6:265-276

Santelices B (2007) The discovery of kelp forests in deep-water habitats of tropical regions. PNAS 104:19163-19164

Santelices B, Bolton JJ, Meneses I (2009) 6. Marine algal communities. In: Whitman JD, Roy K (eds) Marine macroecology. Chicago University Press, Chicago, pp 153-192

Sasaki H, Kawai H (2007) Taxonomic revision of the genus Chorda (Chordaceae, Laminariales) on the basis of sporophyte anatomy and molecular phylogeny. Phycologia 46:10-21
Saunders GW, Druehl LD (1991) Restriction enzyme mapping of the nuclear ribosomal cistron in selected Laminariales (Phaeophyta) a phylogenetic assessment. Can J Bot 69:2647-2654

Saunders GW, Druehl LD (1992) Nucleotide sequences of the smallsubunit ribosomal-RNA genes from selected Laminariales (Phaeophyta)—implications for kelp evolution. J Phycol 28:544-549

Saunders GW, Druehl LD (1993) Revision of the kelp family Alariaceae and the taxonomic affinities of Lessoniopsis Reinke (Laminariales, Phaeophyta). Hydrobiologia 260(261):689-697

Saunders M, Metaxas A (2007) Temperature explains settlement patterns of the introduced bryozoan Membranipora membranacea in Nova Scotia, Canada. Mar Ecol Prog Ser 344:95-106

Saunders GW, Kraft G, Tan IH, Druehl LD (1992) When is a family not a family? Biosystems 28:109-116

Selivanova ON, Zhigadlova GG, Hansen GI (2007) Revision of the systematics of algae in the order Laminariales (Phaeophyta) from the Far-Eastern seas of Russia on the basis of molecular-phylogenetic data. Russ J Mar Biol 33:278-289

Setchell WA, Gardner NL (1925) The Marine Algae of the Pacific coast of North America, vol 8. University of California Press, Berkeley

Setchell WA, Gardner NL (1930) Marine algae of the Revillagigedo Islands expedition in 1925. Proc Calif Acad Sci Ser 4 19:109-215

Sheppard C, Price A, Roberts C (1992) Marine ecology of the Arabian region. Academic Press, London

Smit AJ (2004) Medicinal and pharmaceutical uses of seaweed natural products: a review. J Appl Phycol 16:245-262

Spalding MD, Fox HE, Allen GR, Davidson N, Ferdaña A, Finlayson SON, Halpern BS, Jorge AL, Lombana AL, Lourie SA, Martin KD, McManus JM, Recchia CA, Robertson J (2007) Marine ecoregions of the world: a bioregionalization of coastal and shelf areas. Bioscience 57:573-583

Stam WT, Bot PVM, Boele-Bos SA, van Rooij JM, van den Hoek C (1988) Single-copy DNA-DNA hybridizations among five species of Laminaria (Phaeophyceae): phylogenetic and biogeographic implications. Helgoländer Meeresunters 42:251-267

Stegenga H, Bolton JJ, Anderson RJ (1997) Seaweeds of the South African west coast. Contr Bol Herb 18: 655 pp

Suzuki S, Furuya K, Kawai T, Takeuchi I (2007) Growth and annual production of the brown alga Laminaria religiosa introduced into the Uwa Sea in southern Japan. Phycol Res 55:272-277

Taylor WR (1945) Pacific marine algae of the Allan Hancock expeditions to the Galapagos Islands. Allan Hancock Pac Exped 12:iv + 528

Tom Dieck I (1992) North Pacific and North Atlantic digitate Laminaria species (Phaeophyta)—hybridization experiments and temperature responses. Phycologia 31:147-163

Tom Dieck I (1993) Temperature tolerance and survival in darkness of kelp gametophytes (Laminariales, Phaeophyta)—ecological and biogeographic implications. Mar Ecol Prog Ser 100:253-264

Tom Dieck I, de Oliveira EC (1993) The section Digitatae of the genus Laminaria (Phaeophyta) in the Northern and Southern Atlantic: crossing experiments and temperature tolerances. Mar Biol 115:51-160

Troell M, Robertson-Andersson DV, Anderson RJ, Bolton JJ, Maneveldt G, Halling C, Probyn T (2006) Abalone farming in South Africa: perspectives on kelp resources, abalone feed, potential for on-farm seaweed production and socio-economic benefits. Aquaculture 257:266-281

Uwai SY, Nelson W, Neill K, Wang WD, Aguilar-Rosas LE, Boo SM, Kitiyama T, Kawa H (2006) Genetic diversity in Undaria pinnatifida (Laminariales, Phaeophyceae) deduced from mitochondria genes origins and succession of introduced populations. Phycologia 45:687-695

Uwai S, Arai S, Morita T, Kawai H (2007) Genetic distinctness and phylogenetic relationships among Undaria species (Laminariales, 
Phaeophyceae) based on mitochondrial cox3 gene sequences. Phycol Res 55:263-271

Waters JM (2008) Driven by the West Wind Drift? A synthesis of southern temperate marine biogeography, with new directions for dispersalism. J Biogeogr 35:417-427

Wattier R, Maggs CA (2001) Intraspecific variation in seaweeds: the application of new tools and approaches. Adv Bot Res 35:171-212

Wynne MJ (2009) Marine algae and early explorations in the upper North Pacific and Bering Sea. Algae 24:1-29
Yoon HS, Lee JY, Boo SM, Bhattacharya D (2001) Phylogeny of the Alariaceae, Laminariaceae, and Lessoniaceae (Phaeophyceae) based on plastid-encoded RuBisCo spacer and nuclear-encoded ITS sequences comparisons. Mol Phylogenet Evol 21:231-243

Yotsukura N, Takashi D, Motomura T, Horiguchi T, Coleman A, Ichimura T (1999) Little divergence in ribosomal DNA internal transcribed spacer-1 and -2 sequences among nondigitate species of Laminaria (Phaeophyceae) from Hokkaido. Jpn Phycol Res 47:71-80

Zemke-White WL, Ohno M (1999) World seaweed utilisation: an end of century summary. J Appl Phycol 11:369-376 